\title{
The Construction of Tourism Management Practical Teaching System
}

\author{
Liumei Huang \\ Guilin Tourism University, Guilin, China
}

Keywords: Tourism, Tourism management, Management major, Practice teaching, Construction

\begin{abstract}
In recent years, with the continuous development of social economy, the tourism industry has also been developed. This kind of development poses the demand for high-quality professional and technical personnel. To strengthen the discipline construction of tourism management major and to construct a practical teaching system with the characteristics of higher education are the important topics facing the tourism management major at this stage. Based on the demand of professionals in tourism industry, this paper analyzes and discusses the construction of practical teaching system of tourism management major.
\end{abstract}

\section{Introduction}

It can be said that tourism management education in our country is not a long time, but because it mainly emphasizes professional basic theory teaching, while highlighting vocational skills training, it is recognized by society, so practice teaching and vocational skills training to become tourism management education Important feature, but also the vitality of the place, at the same time become an important property requirements of the construction of practical teaching system [1]. The tourism management major should construct the practice teaching system on the basis of following the general laws of teaching in the process of teaching so as to better train qualified personnel for tourism enterprises in society.

Practical teaching is an important project in the education of higher education. At present, the practical teaching of tourism management major is rather scattered and trivial, making it hard to carry out systematic practical teaching so as to enhance students' professional skills and overall quality. In view of the problems reflected in higher tourism management major, analyzing and summarizing ideas, enhancing the depth and effectiveness of school-enterprise cooperation, training talents in social practice environment and constructing and perfecting the practice teaching system have achieved the effect of enhancing the comprehensive level of tourism management professionals.

\section{Problems in Tourism Teaching in Chinese Institutions of Higher Learning}

\subsection{Insufficient teaching practice}

Tourism management discipline itself requires a lot of practical experience in order to better play a professional advantage, serving the broad customer base. Traditional tourism management major teaching, more emphasis on the teaching of theoretical knowledge, training for practical ability is limited, the basic theory of knowledge is too much, the application of less knowledge-based skills, lack of practice also contributed to the theoretical knowledge of the situation is difficult to consolidate [1]. Students through theoretical study is difficult to achieve the requirements of vocational skills, the need for knowledge, skills, experience, attitude, etc. have a comprehensive ability to use and high overall quality. Under the theoretical teaching mode, it is difficult to combine with practice, which results in the weak vocational ability of students and the lack of practice teaching, which has a great influence on the students' development of tourism management specialty.

\subsection{Ability to develop more comprehensive, comprehensive quality need to be improved}

Tourism management major teaching mainly theoretical knowledge, practice teaching mainly to professional skills training, this is only learning tourism management professionals need to have the basic skills, for the comprehensive ability to develop relatively weak. Some students cannot correctly 
analyze the actual problems encountered in the process of practice, and the ability to solve problems is even more worrying [2]. The situation where the practice teaching is more unitary also exists ubiquitously and cannot encompass most of the situations that may be encountered. This makes it necessary to raise one-sidedly and comprehensively the quality of students' abilities.

\subsection{School-enterprise cooperation surface}

Training rooms are equipped with colleges and universities, funding and other factors, facilities and equipment is simple, difficult to implement the school training room in place, only a simple operational training. The cooperation between school and enterprise is superficial and it is difficult to carry out long-term and deep cooperation. The practical and experienced personnel needed by enterprises do not have much sense of responsibility for the cultivation of talents [2]. Although the cooperation between school and enterprise is further deepened, the requirements of enterprise management make it is difficult to devote too much energy to the project of practical teaching in schools, which leads to the situation of too narrow practical teaching platform and the win-win situation that the cooperation between school and enterprise requires deep solution.

\subsection{The construction of practical teaching platform is not enough}

Difficult to meet the requirements of comprehensive practical ability training at present, the common practice teaching model is mainly the combination of school laboratories and school-enterprise two, but also of practical significance. However, the practice teaching platform in colleges and universities generally has the problem of poor construction.

On the one hand, due to funding and design reasons, the school laboratory there are two major problems: First, the construction of related laboratories cannot be put in place. Generally, there are few laboratories in higher tourism colleges and universities, which can only provide limited practical training for individual training courses. Tourism management teaching or even complete lack of practice places in the school, or do not practice training at all. Second, facilities and equipment are simple, backward, the lack of environmental atmosphere. Only simple basic operation training, it is difficult to conduct a comprehensive scenario training; only basic service skills training, it is difficult to carry out a higher level of management training [1]. On the other hand, the cooperation between school and enterprises is superficial and it is difficult to establish a close, long-term and recurrent cooperation relationship. Off-campus internship base is an important place to cultivate students' comprehensive practical ability. Objectively speaking, due to the lack of responsibility of enterprises to participate in the training, the operation and management of enterprises are complicated and complicated, leading to the lack of enthusiasm for enterprises to cooperate with schools and enterprises. Subjectively, schools pay little attention to practical teaching. These two factors have restricted the effective development of school-enterprise cooperation and education. Currently, off-campus internship in tourism universities only stays at grassroots service level, and internship at management level is difficult to be implemented, affecting the comprehensive practice ability of tourism management students.

\section{The Construction Principles of Practical Teaching System of Tourism Management Specialty in Vocational Colleges}

\subsection{Interactive communication principle}

In the practical teaching of tourism management major, teachers should play an active guiding role, fully guarantee students' dominant position in the practice process, and guide students to actively and actively engage in practical teaching through effective interaction between teachers and students Among them, this is an important measure to cultivate students' abilities of interpersonal communication, adaptability and practical ability as well as the ability to use theoretical knowledge to solve practical problems.

\subsection{Principles of scientific planning and design}

The practical teaching of tourism management major in vocational colleges should set up special 
departments, arrange professional personnel to take charge and management, make the scientific planning and design of practice teaching, avoid the blindness and arbitrariness in practice teaching, and improve the practical teaching Pertinence and effectiveness, do a good job of theoretical teaching and practical teaching convergence.

\subsection{Highlight the principle of characteristics}

Outstanding features of vocational colleges to improve teaching quality and professional visibility of important initiatives. Therefore, on the basis of complying with the teaching philosophy and training objectives of tourism management major, the construction of practice teaching system should highlight the characteristics, highlight its advantages and characteristics of running a school, and create favorable internal and external conditions for the cultivation of students' professional abilities and future employment.

\section{The Significance of Constructing Practical Teaching System in Tourism Management Specialty}

Professional foundation course is the starting point for students to contact the profession, mostly in the teaching process of descriptive and operational content, simple knowledge transfer is very negative for students' understanding and memory, in this case, the construction the importance of the practical teaching system for tourism major is highlighted. Teachers should be combined with the actual teaching of the curriculum, by watching video, on-site teaching and other ways to deepen students' perceptual knowledge of future work [2]. To organize students to some famous hotels and tourist attractions in-depth understanding of the elements of the industry to enable students to better understand the professional curriculum to further stimulate students' professional interest. On the basis of this, a practical teaching system is constructed and the theoretical teaching and practice teaching are organically integrated to better train a large number of tourism management personnel for the society.

\section{Construction of Practical Teaching System of Tourism Management Specialty}

Tourism is an empirical service industry with high requirements for the comprehensive ability of employees. In the field of tourism management specialty teaching in institutions of higher learning, it is necessary to carry out the practice teaching mode and combine the theory with the practice with the comprehensive ability cultivation as the fundamental purpose to cultivate the comprehensive practical talents and construct a practical teaching system combining theory with practice.

\subsection{Practical teaching plan adjustment}

The experiment teaching mainly consists of the basic course of the specialty and the experiment of the compulsory course, which is mainly conducted in the simulation laboratory. The basic skills of the students are trained according to the basic knowledge, and the students' ability of independent analysis and experiment is trained, such as coordination and liaison Customer service, sales rooms, simulated tour guide training [3]. Organization of professional lectures, to the hotel, famous tourist attractions to study, understands the relevant elements of the tourism industry. Organized by the school for a period of 6 months of business practice is in the internship process to deepen the understanding of the industry and thinking.

\subsection{Improve and improve the practice base}

Campus internship base construction should be simulated hotel management laboratories, landscape design laboratories, etc., while in accordance with industry standards for the improvement of related facilities. The functions of the laboratory should be diversified, so that students can meet a variety of internship needs, so that students can conduct a variety of internships in the same place of practice. The related industries run by the institutions are standardized practice bases, such as travel agencies run by the school. There are marketing departments, design operation departments and other 
business departments under the travel agencies to provide practical training for professional students [4]. Other travel agencies jointly develop some tourism training programs to better provide students with opportunities for daily internship.

\subsection{Construction of practical teaching mode}

Depth cooperation with domestic and foreign hotels, scenic tourist areas and other enterprises to improve the operation mechanism of school-enterprise cooperation, and implemented the $5+3$ talent training mode based on the overall framework of campus personnel training [3]. The $5+3$ talent training mode mainly refers to the basic ability training for 5 semesters, productive training for 1 semester, and sentimental internship for 1 semester, internship for 1 semester. Promote the improvement of various occupational skills of students, and finally successfully meet the requirements of employers.

\subsection{Taking ability as starting point to carry out construction of practical teaching system}

In today's era of diploma education requirements gradually reduced, more emphasis on personal ability. The requirements of professional post ability are the most basic starting point for recruiting talent [3]. In the construction of practical teaching system, we need to analyze the professional post ability requirements, as the goal and basis of practical teaching to market personnel demand for talent training, business and market demand to locate the current curriculum model and Practical teaching system.

\subsection{Deepening the cooperation between schools and enterprises and establishing industrial entities}

The establishment of school-enterprise cooperation can enable students to have more contact with their actual positions during school, enter the society, and enhance their social awareness and adaptability to professional work. Although school-enterprise cooperation has been carried out at present, there are still some problems that need to be perfected. The combination of production and learning requires schools and tourism enterprises to establish cooperation and win-win cooperation mode of cooperation [4].

In addition, on the basis of seeking the cooperation between school and enterprise, it is also possible to set up industrial entities and build an independent training base in order to build a post environment that is suitable for students' practice and effectively create an ecological cycle of talents. Both to solve practical teaching problems, but also to improve the practical teaching system structure, but also to provide jobs for my graduates, another tourism industry entity is also a school of support.

\subsection{The introduction of industry standards, development of personnel training programs}

School-enterprise cooperation requires enterprises to provide schools with talent demand information, and gives suggestions for personnel training, specific job requirements, knowledge level requirements, and skill level requirements and so on [4]. Schools according to the requirements of enterprises improve the teaching system, jointly develop training objectives and teaching plans to achieve the common cultivation of qualified personnel so that students can better adapt to social needs.

\subsection{Arrange internship in-depth cooperation mechanism}

According to personnel training programs and teaching programs, regular selection of professional students to enter the travel enterprise internships, internship cycle can be based on the actual situation. Students in the internship phase can receive internship of professional and technical personnel guidance, which can be a smooth graduation and early entry into society to establish a good foundation [5]. Schools and enterprises need consensus and common development to establish close contact.

\subsection{School-enterprise mutual appointment}

The cultivation of talents has a great bearing on the ability of teachers to promote the mutual 
appointment of both the school and the enterprise, hire senior technicians from enterprises or tourism experts to serve in our school and undertake some training tasks, which are of many aspects such as personnel training, teaching material reform and preparation all help. The substitution of corporate culture can also affect students well, and draw on the valuable experience of outside experts and the solution and analysis of practical experience to improve students' awareness and comprehensive ability [5]. Our school tourism management professional teachers can also enter the enterprise to serve, after a certain period of return to the campus, enhance teachers' practical experience, and better serve students in personnel training.

\subsection{Founding industry}

During the cooperation between school and enterprise, after mutual agreement of both parties, the names of internship bases and plaque production will be confirmed and their respective popularity will be raised. They can publicize through the campus network and corporate website, and actively carry out practical training, internship and scientific research cooperation projects [5].

In addition, the school may apply for the establishment of or in conjunction with the establishment of a more independent business travel enterprises, the establishment of industrial enterprises, the establishment of a more independent practice teaching base, the school-based business trial run, and actively mobilize students to participate. For students practice, employment, learning to provide a more professional platform to enable personnel to cycle development, and promote the construction of practical teaching system and improvement.

\section{Conclusions}

To sum up, in recent years, with the continuous development of tourism, more and more schools have set up tourism management majors in China. During the training of tourism management professionals, practice teaching is a very important step and should be strengthened Government and school, this article briefly explained the significance of practical teaching of tourism management specialty in this background, and grasped the problems existing in the practice teaching of tourism management major at present, and proposed the construction of practical teaching system Some of my own opinions, hope can provide some reference for the relevant research.

\section{References}

[1] J.H. Shi, Higher logistics management practice teaching system of practical exploration, Logistics engineering and management, 2011, vol.6, pp.31-34.

[2] Y.R. Sun, Practice and teaching of higher judicial police professional practice teaching system, Journal of Guangxi Administrative Cadre Institute of Politics and Law, 2013, vol.6, pp.21-24.

[3] Y.Y. Chen, On the practical teaching of tourism management major in colleges and universities thinking, Chifeng University Journal: Natural Science, 2013, vol.23, pp43-46.

[4] A.H. Zhao, based on the concept of CDIO tourism management professional five in one practice teaching system construction, University Education, 2013, vol.3, pp.15-18.

[5] H.T. Cui, College of tourism management integrated practice teaching system construction and implementation, Journal of Taiyuan urban vocational and technical college, 2014, vol.7, pp.65-68. 